\title{
A Discursive Study of the Unscheduled Dialogue in G. Kanafani's Returnee to Haifa
}

\begin{abstract}
By Ibrahim A. El-Hussari*
In Ghassan Kanafani's tale, Returnee to Haifa, "What's in a name?" is a restless question in search of an answer. Although it does not openly speak to any specific situation, this question turns into a clue to understanding the crosssectional narrative discourse of the tale. All four of the main characters are enmeshed in an untimely dialogue over identity and belonging, and find themselves facing a multifaceted dilemma that intensifies the urge for reframing the concept of identity and belonging in regards to homeland and blood kinship. Accordingly, this paper reviews attribution theory and refers to it as a research tool to look at the significance of the messages embedded in the conflicting discourses that shape the unorchestrated dialogue through which all the characters involved tend to tell and defend different versions of the one story, the Palestinian Nakba. ${ }^{I}$
\end{abstract}

Keywords: Kanafani, Haifa, discourse, homeland, dialogue, memory, identity

\section{Introduction}

"What's in a name? That which we call a rose by any other name would smell as sweet."

(Shakespeare 2009, Act II, sc. ii, 2)

"What's in a Name?" sounds too elusive for a clue used in an academic research paper. However, I am not hunting for an enigmatic title to impress my readers. I just came across the above quote while re-reading William Shakespeare's Romeo and Juliet (1597) to outline my literature course syllabus prescribed for undergraduate students taking my literature course (ENG311) at The Lebanese American University in Beirut, Lebanon. In her soliloquy, and upon learning of Romeo's identity as a foe in the context of the Veronese Montague-Capulet family feud atmosphere, Juliet whispers nonchalantly, "What's in a name?" to dismiss all the negative connotations threatening to ruin her fresh, calf love for Romeo. This exclamatory question bears some significance in shaping Juliet's character and fate. Juliet's discourse of evasion betrays an unspoken challenge to her family's

\footnotetext{
*Professor, Lebanese American University, Lebanon.

${ }^{1}$ An Arabic term meaning mass catastrophe. Nakba Day (May 15, 1948) is remembered for the massive harm done to two-thirds of the Palestinian civilians (including the Arab characters featured in the tale) who were intimidated through mass murder inflicted on them by the Zionist Jewish immigrants to Palestine under British mandate. Those armed Zionist settlers used force to terrorize thousands of Palestinian civilians and their families who would soon run for their lives and become homeless, dispossessed refugees in the neighboring Arab countries and beyond. The hope to be back home within a short period of time, as promised by the Arab Salvation Army, then turned into air bubbles. Ironically, Israel was created as a Jewish homeland in part of Palestine, and the Middle East conflict has been exacerbated ever since.
} 
strict orders, and to the Veronese feudal lords whose hollow pride foreshadows the tragic fate of the two young lovers in the last scene of the play.

In yet another context, the same question "What's in a name?" assumes a different level of connotation. In his highly acclaimed novel The Pessoptimist (1985), Emile Habibi ${ }^{2}$ depicts an absurd situation between the protagonist of his tale and a security police officer. Sa'eed, the character-narrator, is a Palestinian civilian handcuffed as a suspect and is driven into a military lorry by his jailor, who is an Israeli police officer with a machine gun. While seated in the lorry heading for Shatta prison for further police interrogation, they come across one of Palestine's most fertile and most bountiful plains in the Galilee mountainous region. Sa'eed feels excited and identifies the scenic view of the plain as Marj Ibn Amer [the plain of Ibn Amer], but is soon interrupted and hushed by the police officer.

I found that we were then at a crossroads between Nazareth and Nahal, passing the plain of Ibn Amer.

"Oh, I see we're in the plain of Ibn Amer."

Obviously annoyed, he [the Israeli police officer] shouted and corrected

me: "No, it is the Yizrael plain!"

"What's in a name?" I soothed him.

(Habibi 1985, pp. 123-124)

In the above quote, the question Sa'eed uses to defuse the anger in his jailor betrays a discourse of tactical withdrawal from an inevitable clash with the officer due to situational power relations. Showing the submissive side to his jailor, Sa'eed simply plays the game of the weaker, for he could not have evaded the situation otherwise.

However, in Ghassan Kanafani's Returnee to Haifa (1969), there is much more than love, passion and excitement in a name. The discursive features of the tale evoke a network of images that defy the ordinary expectations of both the reader and the narrator by hinting to big issues that need to be interpreted when properly contextualized in the course of action. When the whole country is captured and renamed, when the left-behind baby is found, adopted and renamed, and when places and private property are expropriated and renamed, then the original name of each one of these items must be based on a story behind which stands a cause that assumes some sort of significance. In this connection, this paper looks at the seemingly irreconcilable basic issues embedded in the dialogic language shared by the four main characters whose voices are constantly made distinct but distant as the dialogue among them keeps running less smoothly

\footnotetext{
${ }^{2}$ Emile Shukri Habibi (1922-1996) is a Palestinian man of letters, a journalist and a political activist who stayed in Haifa after the creation of the Zionist state of Israel as a Jewish homeland in Palestine in 1948 and the dreadful mass expulsion of two-thirds of its population. His novels shun the existentialist angst caused by the Palestinian national tragedy to embrace the laughter emerging from his use of satire, irony, cynicism and burlesque. The use of such an unprecedented narrative discourse in modern Arabic literature is believed by most of his critics to have heightened the tragedy of the Palestinian mass exodus and widened the sphere of public awareness of the question/ cause of Palestine.
} 
towards the end of their very first unscheduled encounter. To this effect, the paper explores the following research question: to what extent can the language of the unorchestrated dialogue between the interlocutors inform of their conflicting discourses?

\section{Literature Review}

Discourse analysts challenge the common-sense view that language is a purely descriptive medium used to convey information about the real world. They argue that language actually constructs and shapes the real world, as well as our views of it, hence the varied interpretations of the misapprehension between words and reality (Potter and Wetherell 1987, Potter and Edwards 1992, Goodman 2007, Stokoe and Edwards 2006, Meyers 2010). This assumption sounds logical when it comes to passing a causal judgment on people's social behavior in specific situations, where time, space and culture count as basic elements causing that behavior to occur. In the same vein, humans are usually motivated to assign causes to their situational responses. They tend to explain and justify a certain action they take by attributing its occurrence to one or more causes. Social psychologists call this process attribution theory.

Psychological research into attribution began with the work of the Austrian psychologist Fritz Heider. Heider (1958) believes that people are naive psychologists trying to make sense of the social world. That's why, he claims, they tend to see cause and effect relationships, even when there is none! Heider does not develop a theory himself, but his focus on certain themes is taken up by others for further academic study in the field. As a matter of fact, Heider has put forward two main ideas which turn out to be influential in regards to attribution, namely dispositional and situational attributions. Dispositional attribution assigns the cause of behavior to some internal characteristics of a person, rather than to outside forces. Situational attribution assigns the cause of behavior to some situation or a series of events outside a person's control, rather than to some internal characteristics. Consequently, Heider's notion of attribution was advanced into a theory with application in the second half of the twentieth century. Scholars, namely Harold Kelley, Bernard Weiner, Sandra Graham \& Valerie Folkes, and Jonathan Potter \& Derek Edwards, all contributed to the making of the attribution theory.

A brief definition of the notion of attribution as a hypothetical term reads as follows: "Attribution theory is concerned with discovering the way by means of which we come to conclusions about the causes of our own and other people's social behavior" (Potter and Edwards 1990, p. 1). However, the conclusions we may reach are not necessarily similar or identical. As a matter of fact, social behavior is a complex term. It is more so when short descriptions of a certain situation reported by one person is selective of facts. Besides, our perception of causality is often distorted by our needs and certain emotional biases, especially when we explain the behaviors of others (Heider 1958). This assumption is also endorsed by Weiner (1992) when he argues that causality influences emotional 
responses to the outcome of a task. Nevertheless, attribution as a process shaping our causal judgments entails much more than that. As a matter of fact, when sensory data, particularly culture-specific items, evoke some underlying cause in the world, attribution theory looks at a possibly extended level of relationships beyond the personal. Hence, it is inevitable to have wider definitions of the term, as shown hereunder.

a. Attribution theory deals with how the social perceiver uses information to arrive at causal explanations for events. It examines what information is gathered and how it is combined to form a causal judgment (Fiske and Taylor 1991, p. 23).

b. Attribution theory is concerned with the perceptions people have about the causes of their own and others' behavior and the effect that these perceptions have on their subsequent behavior (Weiner 1986, p. 29).

c. A major influence on how people behave is the way they interpret the events around them. People who feel they have control over what happens to them are more likely to accept responsibility for their actions than those who feel control of events is out of their hands. The cognitive process by which people interpret the reasons or causes for their behavior is described by attribution theory (Kelley 1967, pp. 55-56).

In this connection, attribution theory accommodates a wide fan of items that are likely to shape various types of personal behavior. These items range from the rational to the emotional, and from the personal to the impersonal. For instance, people often make causal attributions in a rational manner as they assign some cause to a certain action or behavior observed. The cause here could be a visual memory reactivated to reconstruct a past that once was a reality, or to retrieve a way of living that once was part of a culture dimming out. However, being a process in the first place, attribution theory is likely to host some factors where motives, intentions, sentiments and memories manifest themselves in an individual's overt behavior.

As the present study tends to elaborate on the significance of memories, both individual and group, it should be noted here that attribution theory has given casual attention to this item as a central motive for a series of actions and reactions. Hence, varied judgments of memories produced by adult men and women as well as children differ. In this connection, it is argued that people assume the testimony of an adult to be more credible and accurate than that of a child, based on the assumption that adults are better memory reporters (Leippe et al. 1992, p. 187). Besides, adults who recall domestic details from the near past through the general principles of causality help us understand some of the human behavioral patterns in the present. To this effect, looking back, both impatiently and passionately, to recall and reconstruct a family life lost, or a house confiscated, or an occupied homeland renamed is upheld by a strong memory that maintains continuity of interaction between the emotional and the national. In this context, interaction between past and present takes place when we use our mental images of the present to reconstruct our past (Halbwachs 1992, p. 22). It is true that individuals remember, but what is being remembered requires a social context of a particular time and space. In practical terms, commemorative collective rituals 
play a central role in articulating the shared memories of some events (Litvak 2009).

Furthermore, one type of attribution theory is meant to explain particular historical events to help us make sense of the world around us. However, the outcome differs in regards to the rules of the game framing the existing power relations. In case of dialogue between the dominant and the dominated, this explanatory model attributes historical memories and recalled events to specific stable or unstable causes. The dominant party usually uses formal historical documents "to validate successive deformation, manipulation and appropriation of the memory of the dominated" (Nora 1989, p. 16). In contrast, the dominated party uses memory, most often in the form of reporting oral historical narratives, as one of the means available to validate national history (Pappe 2006). As this type of attribution uncovers two conflicting discourses, the dominated may retreat, but not concede, due to disproportion in power relations. Historical memories may be silenced for some time, but never forgotten. In fact, those memories can be transformed into political assets where, "the present is interpreted through the lens of the unforgotten past" (Nora 1989, p. 20).

Nevertheless, attribution theory is criticized as being mechanistic and reductionist for assuming that people are rational, logical and systematic thinkers (Graham and Folkes 2014). The theory also falls short of addressing important issues, such as colonial, cultural, racial, and even mythical narratives ${ }^{3}$ as factors that are likely to ascribe causes to certain behavior, such as blame. This has been addressed extensively by discourse analysis where language is studied to understand various criteria, including how language influences the attribution style of its users.

Based on the above review of the literature, this research paper looks at the conflicting discourses of the main characters involved in a seemingly pointless dialogue over identity and belonging. All of the four characters featured in Returnee to Haifa find themselves on the defensive, as their semi-rational dialogue is replete with memories recalled to justify their hazy present situations. Concurrently, this paper looks further at the discursive features of the dialogic language used and how speakers construct themselves and others in discourse.

\section{The Tale}

Returnee to Haifa is the story of a Palestinian couple, Sa'eed S. and his wife Safiyyah, who, on the evening $9^{\text {th }}$ of April, 1948, were led by the British colonial troops to Haifa harbor and asked to board an unknown boat about to sail off to nowhere. ${ }^{4}$ The boat was loaded with many other Palestinian civilian natives from the city of Haifa and its surrounding neighborhoods. The two dumbfounded passengers had no idea why they were ordered to leave their own home in Haifa,

\footnotetext{
${ }^{3}$ Reference is made to the myth of The Promised Land.

${ }^{4}$ The British troops wanted them to run for their lives when all of a sudden the Zionist militant Haganah gangs attacked Haifa on the $9^{\text {th }}$ of April, which is 35 days before the withdrawal of Britain from Palestine as officially announced on May 14, 1948.
} 
only to discover that they had become homeless refugees. Eventually, they were led by the officers of the International Society of Red Cross to inhabit a tent in one of the refugee camps in the outskirts of Ramallah, a city in the Palestinian West Bank, then under Jordan. In the wake of the 1967 Six-Day War between the Arabs and Israel, the remaining part of Palestine was lost, and the Israeli occupation authorities started an open-bridge policy with the newly-occupied Palestinian territories and Jordan. While on board the boat, Sa'eed and Safiyyah found out that they had left behind their five-month-old baby boy, Khaldun. The baby was found by the Jewish Agency ${ }^{5}$ that had brokered an agreement with an old childless couple, Ephrat and Miriam Koshen, ${ }^{6}$ immigrating from Poland to Palestine. This old couple would soon be the tenants of the house in which the baby was found. Upon the request of the Jewish Agency, Khaldun was handed over to the Koshens, who adopted the baby and renamed him Dov. After the passage of 20 years, Sa'eed and Safiyyah drove to Haifa in order to check on their own "baby" and house in Haifa. Miriam, a widow now, was expecting them to show up, thanks to the open-bridge policy across borders. Silence, interrupted by little talk, filled the atmosphere of the house which had not changed much, including the three peacock feathers in the vase. Expecting their son, Khaldun, to show up in the evening, Sa'eed and Safiyyah found themselves standing in front of a twenty-year old stranger called Dov, who had just come back from a military training exercise, wearing an $\mathrm{IDF}^{8}$ military uniform. The dialogue held among the four characters over a lot of things, including parental and filial relationships, as well as identity and homeland, led to nowhere due to the tactical defensive attribution strategy they used in order to justify the situations they had passed through. Not admitting that he was a loser, Sa'eed drove back to Ramallah wishing that his younger son, Khaled, had joined the newly formed forces of the Palestinian armed resistance movement against the Zionist occupation of Palestine.

\footnotetext{
${ }^{5}$ A very influential Jewish organization whose main goal was to facilitate Jewish immigration from Europe to Palestine during the British Mandate for Palestine. The Agency was also entrusted to manage the property of the Palestinian Absentees [sic.] until further notice.

${ }^{6}$ The Koshens, who came to Palestine from Poland, are introduced as Holocaust and Auschwitz survivors.

${ }^{7}$ Reference is made to the June 1967 War between Israel and three Arab states (Egypt, Syria and Jordan) after which all Palestine, including Jerusalem, was captured by Israel who announced right away a policy of open bridges. Sa'eed and Saffiyah crossed the borders from Ramallah to Haifa through the Mandelbaum Gate on June 30, 1967.

${ }^{8} \mathrm{IDF}$ refers to the Israeli army, and it stands for Israeli Defense Forces, which Dov has just joined as a soldier.
} 


\section{Discussion}

Returnee to Haifa is a complex, open-ended tale whose sophisticated narrative discourse traverses the unresolved painful memories of its characters to settle nowhere soon after. The conflicting vocal discourses of the four characters involved in a seemingly rational dialogue spring from the dark spots irritating their private worlds. Resorting to defensive attribution strategy, each one of those characters has a story to tell to maintain a robust, unalienable position. In discursive psychology as well as interpersonal communication and social psychology, it is language that is more likely than other factors to "construct the world and the people's views of it" (Potter and Edwards 1992, p. ii).

In Returnee to Haifa, the four characters share the above theoretical assumption when it comes to explaining the various situations they have passed through. It is true that they all have seemingly separate stories and face different challenges, but it is also true that they are all part and parcel of the big story framed by their unscheduled encounter where they hold an informal debate, rather than a dialogue, over big issues regarding homeland, homelessness, dispossession and blood kinship. Apparently at a crossroads due to the conflicting discourses, each one of them has a say in those issues, especially the one defining paternal and filial relationships. As a matter of fact, this issue becomes the central point dramatizing the clash, not only in form of an external struggle between Sa'eed S. and Miriam Koshen (the tenant of his house), but also in the form of an internal struggle within Sa'eed himself. The internal struggle is between a photographic memory storing up an intimate day-dream nourished for twenty years of exile, and a stark reality slapping the day-dreamer hard in the face. The four characters share similar discursive features of the language describing the defensive attribution strategy. As for Sa'eed, the round trip he has taken with his wife to recover a hazy past seems to have unfolded abruptly. Sa'eed, a Panglossian day-dreamer at the beginning of the journey, matures in no time into a man with a sarcastic vision when he faces reality and receives a hard slap in the face.

This part of the paper is divided into two sub-sections, each of which illuminates one side of the central narrative. This is done through a discursive study of the language used by the four main characters, namely Sa'eed, Safiyya, Miriam and Khaldun/Dov.

\section{The First Encounter}

This encounter takes place between the Palestinian couple and the tenant of their house in Haifa. Sa'eed and Safiyyah are sketched as two journeying souls in search of an illusion. They drive off from Ramallah, under the Israeli military occupation, to Haifa, the city of their birthplace and early life, hoping to redeem a past they have lost for twenty years due to mass expulsion. ${ }^{9}$ While journeying, Sa'eed recalls their intimate memories to reassemble the past: Khaldun, their left-

\footnotetext{
${ }^{9}$ Mass expulsion of the civilian Palestinians started on April 9, 1948 when, all of a sudden, the Jewish militant gang, Haganah, attacked the city of Haifa with full coordination with the British colonial troops in the city.
} 
behind baby in arms, their house which they describe to the last detail, the road they used to take in that part of the city, the neighborhood, and some other details. In this context, memory is extremely treasured by the Palestinians for it is the only thing left to them after the occupation of their land and the life of deprivation they would lead as homeless refugees afterwards. To quote Meir Litvak, the Jewish Harvard professor of history:

While true for every nation, memory is particularly appropriate for the Palestinians as a semi-diasporic people still engaged in a struggle for statehood and a process of nation building (Litvak 2009, p. 29).

Sa'eed knows the topography of the region by heart, so he makes it to his own house in Haifa easily. However, standing on the doorstep for a moment, Sa'eed sounds like a stranger gazing at the door name plate, as he exclaims quietly:

- "They changed the bell."

He was silent a moment, then added: "And the name. Naturally."

(Returnee to Haifa, 26)

Safiyyah, dumbfounded by the door of her own house, remains a passive listener most of the time. Asked by the tenant, an old woman called Miriam Koshen, to come in, the couple feels spellbound by almost the same interior design of the house they were forced to leave twenty years ago. However, old Miriam, now the host, breaks the spell when she implies that she shares in their experience of being victimized, for she is an Auschwitz survivor. Her discourse is in no way offensive, especially when asked how she happens to know who they are.

-"You are the owners of the house. I know that. I have been expecting you for a long time."

-"How do you know?" Sa'eed and Safiyyah both asked the question simultaneously.

The old woman continued to smile. Then she said:

- "From everything. From the photographs, from the way the two of you stood in front of the door. The truth is, ever since the war ${ }^{10}$ ended many people have come here, looking at the houses and going into them. Every day I said that surely you would come." (Returnee to Haifa, 28-29)

It may be argued that this encounter portrays a scene that betrays a victimblaming language. However, this assumption is soon proven invalid as there is no expression called "victims of victims." 11 The Jewish victimhood, promoted worldwide by the Holocaust narratives, is not applicable in the context of justifying the causes of the Palestinian Nakba. The phrase "victims of victims" sounds insensible and ironical as a claim, for victims are not supposed to victimize others who are not their oppressors. To make it clear enough, let's have a look at the story of the

\footnotetext{
${ }^{10}$ Reference to the 6-Day War of June 1967 between Israel and three Arab countries (Egypt, Syria and Jordan).

${ }^{11}$ The phrase "victims of victims" is mentioned by Amos $\mathrm{Oz}$ in his novel The Tale of Love and Darkness, 2004. The use of this phrase in terms of discourse is no more than amelioration.
} 
two Jewish Polish immigrants to Palestine, Miriam and Ephrat Koshen. The Koshens, who were about to fall victim in Auschwitz during World War II, were released after World War II had ended, but they chose to immigrate to Palestine, aided by the Jewish Agency, the mastermind and financier of waves of Jewish immigration into Palestine under the British Mandate. Ephrat Koshen, Miriam's husband, joined the Jewish militant gang Haganah as a fighter against the British troops in Palestine and as an intimidator to scare off the Palestinian civilian communities. The Jewish Agency gave the childless Koshens the house of Sa'eed to live in and the baby son (in arms then) who was left behind. The Koshens accepted the offer and adopted the baby naming him Dov. Thereupon, the dialogue taking place in the first encounter, though rational and polite, implies the first set of conflicting discourses. Hence, Miriam advises the Palestinian couple to wait until Dov [Khaldun] is back home to see how ready he is to recognize his parents. In taking this move, Miriam switches her discourse strategy from defensive attribution to evasive attribution through a tactical withdrawal.

More responsibility will be attributed to the harm-doer as the outcome becomes more severe, and as personal or situational similarity decreases (Graham and Folkes 2014, p. 92).

\section{The Second Encounter}

The second encounter takes place between the Palestinian couple and their biological son, Khaldun, in the presence of Miriam. The parents cannot wait to meet Khaldun, who is by now twenty years old, and whose coming on the scene would be decisive in regards to the issue of blood kinship. Miriam remains silent at this moment in time, but she makes a point when she suggests that they all leave it for the young man to make a choice.

For the past twenty years I've been confused, but now the time has come for us to finish the matter. I know who his father is. And I also know that he is our son.

But let's call on him to decide. Let's call on him to choose. He's of age and we must recognize that he's the only one who has the right to choose. Do you agree?

(Returnee to Haifa, 46).

The response comes right away. Saffiyeh agrees that Khaldun/Dov makes a choice. She got up and said, her voice trembling.

"That's a fair choice. I'm certain Khaldun will choose his real parents. It's impossible to deny the call of flesh and blood" (Returnee to Haifa, 46).

Soon after, Miriam senses his coming when someone turns the key into the door key-hole. "It's Dov!", she says, showing a coy smile (p. 57). After that, Miriam is no more part of the game. Her resignation from the scene is also part of her discourse of evasion.

The coming of Khaldun/Dov fills the space around the three people who have been waiting for him impatiently. The sign language in that space around them 
soon betrays a feeling that everybody is taking a hard test. The young man appears in the $\mathrm{IDF}^{12}$ military uniform. He says he has just finished his military afternoon drill, for his name is listed in the Army Reserves. After being introduced to each other, the group splits into two camps whose discourses keep widening the gap of estrangement between them. Dov is now on the offensive, his parents on the defensive. Their conflicting discourses over family blood ties, homeland, and childcare have reached a deadlock, an irresolvable impasse - a fiasco. The following dialogue between father and son says it all and settles the score once and for all in favor of the son.

"Even when they told me - later on - that my original parents were Arabs, it didn't change anything. No, nothing changed, that's certain. After all, in the final analysis, man is a cause." I kept asking myself: "How could a father and mother leave their five-month-old son behind and run off? How could a mother and father not his own raise him and educate him for twenty years? Twenty years? Do you wish to say anything, sir?"

"No," Sa'eed replied briefly and decisively, motioning with his hand for him to continue.

"I'm in the Reserves now, I haven't been in direct combat yet so I can't describe my feelings... but perhaps in the future I'll be able to confirm to you what I'm about to say: I belong here, and this woman is my mother. I don't know the two of you, and I don't feel anything towards you."

"There's no need for you to explain your feelings to me later on. Maybe your first battle will be with a fida'i ${ }^{13}$ named Khalid. Khalid is my son. I beg you to notice that I did not say he's your brother. As you said, man is a cause. Last week Khalid joined the fedayeen. Do you know why we named him Khalid and not Khaldun? Because we always thought we'd find you, even if it took twenty years. But it didn't happen. We didn't find you, and I don't believe we will find you." (Returnee to Haifa, 47-48)

The second encounter between Sa'eed and Khaldun/Dov is unexpectedly explosive. It is the son who turns the tables on the father, who eventually recognizes him as Dov, not Khaldun. The position Dov assumes all the time looks aggressive, while that of Sa'eed looks recessive. Dov's language is not rhetorical; it is both brisk and straightforward. Its discursive features carry a two-level message: one to reproach, the other to edify. Dov's tutorial position drives Sa'eed to retreat sheepishly and search for words, more especially when the issue of identity is viewed as part of their conflicting discourses. In discursive psychological theory, "identity is not something fixed and stable within an individual. This assumption allows for an analysis of 'when' and 'how' identity is invoked and constructed in conversation" (Stokoe and Edwards 2006, p. 60).

Denied by Dov as his real father, Sa'eed resorts to a tactical discourse of retreat, thus admitting defeat indirectly. He whispers to himself that blood kinship is only a transitional reality, and that Khaldun has been "stolen," renamed Dov, and converted into an enemy soldier who might encounter Khaled, his own brother, in the battlefield; so is the case with Palestine, which has been taken by

\footnotetext{
${ }^{12}$ IDF stands for the Israeli Defense Forces.

${ }^{13}$ Arabic term for a guerilla fighter.
} 
force and renamed "Israel." However, one of the statements which has prompted Sa'eed to rethink his own position and earlier assumptions and quit his short visit to Haifa is borrowed from Dov's; it runs as follows: "Man is in the end nothing but a cause" (p. 54). Sa'eed has come to a realization that leaving a baby behind is not that different from leaving a home or a city or a homeland. Memory, no matter how sharp it is, cannot be enough to recover the past. Thanks to Dov, Sa'eed has learned the lesson the hard way. He murmurs unto himself:

"What is parenthood? Man is a cause, what cause? What is homeland? Is it these seats that have remained in place for twenty years? The framed painting of Jerusalem hanging on the wall? ..." (Returnee to Haifa, 83).

The language used throughout the second encounter with Khaldun/Dov marks a point of departure. Sa'eed's discourse has undergone a considerable change.

Our perceptions of causality are often distorted by our needs and certain emotional biases, especially when it comes to explaining the behavior of others (Heider 1958, p. 22).

However, the change is not yet complete. Having been rebuffed recovering a past "stolen," Sa'eed refuses to admit defeat tacitly. On his way back to Ramallah, he seems to be shedding his old skin and wishing for more rounds of combat in the battlefield with the occupation forces of his homeland. However, he foresees that these rounds need a young Palestinian generation, like that of his second son, Khaled, belongs to and represents.

I wish Khaled had joined the fida'yeen [freedom fighters] by now (p. 83).

Having developed a discourse of flight, Sa'eed switches from a day-dreamer feeding on past memory that resists oblivion, to a wishful thinker unable to act. His memories have failed to restore him to a confiscated intimate past, hence he is left with some wishful thinking which likens a Lutheran ${ }^{14}$ dream. Sa'eed allows himself to retreat and withdraw from the scene, leaving enough room for the new Palestinian generation to right the wrong done by their parents for over twenty years.

Endorsing this assumption, Kanafani manages to save his tale from the curse of moral defeat. His narrative technique manages to shield the tale from falling into the hole of wishful thinking by creating an episode in which one of the Palestinian martyrs is featured as a national hero. As none of the main characters in Returnee to Haifa fits for a hero, Kanafani outlines a role in search of a hero who could possibly provide a definitive answer to the implied question "What's in a name?" besetting the world of the tale. The episode recalls the heroic role of the absent hero, Faris al-Lubdah, who fell defending his city of Jaffa in 1948. The framed photo of this martyr is still hanging on one of the walls inside his family

\footnotetext{
${ }^{14}$ Reference to Dr. Martin Luther King, Jr, famous for his iconic phrase "I have a dream" repeatedly voiced during his Lincoln Memorial Speech in Washington, DC. In 1963.
} 
house in Jaffa. Placed there to be cherished with reverence all the time, the photo of Faris al-Lubdah keeps sending clear messages and loaded signals to that effect.

\section{Conclusion}

This research paper has shown that the discursive features of the dialogic language painting the world of Ghassan Kanafani's tale Returnee to Haifa is seemingly more rational than emotional. All of the four characters involved in a smooth-running verbal encounter over big issues, such as victimhood, belonging and identity, plead their causes through a defensive attribution strategy, only to avoid feeling vulnerable to situations that they have no control over. Ironically, however, the outcome of that untimely encounter is provocative enough to make a shift in the protagonist's discourse as he leaves Haifa and drives back to Ramallah. Memories that keep running in the blood of the Palestinian individual families are likely to refuel the collective national repertoire of these people who have been living under occupation or in exile since 1948. Only then would the question "What's in a name?" find a satisfactory answer.

\section{References}

Fiske ST, Taylor SE (1991) Social cognition. New York: McGraw-Hill.

Goodman S (2007) How to conduct a psychological discourse analysis. Critical Approaches to Discourse Analysis Across Disciplines 9(2): 142-153.

Graham S, Folkes V (Eds.) (2014) Attribution theory: applications to achievement, mental health, and interpersonal conflict. New York: Psychology Press.

Habibi E (1985) Al-Waqa's al-Ghariba fi Ikhtifa' Sa'eed Abi an-Nahs al-Mutashael. (The pessoptimist). Translated by S Jayyusi and T La Gassik. New York: Interlink Books.

Halbwachs M (1992) On collective memory. Edited by LA Coser. Chicago: University of Chicago Press.

Heider F (1958) The psychology of interpersonal relationships. Kansas, USA: John Wiley and Sons, Inc.

Kanafani G (1969) Returnee to Haifa and other stories. Translated from the Arabic A'ied ela Haifa by Barbara Harlow and Karen Riley. London \& Boulder: Lynne Rienner Publishers.

Kelley H (1967) Attribution theory in social psychology. In D Levine (ed.), Nebraska Symposium on Motivation, 15, 192-238. University of Nebraska Press.

Leippe MR, Manion AP, Romanczyk A (1992) Eyewitness persuasion: how and how well do fact finders judge the accuracy of adults' and children's memory reports? Journal of Personality and Social Psychology 63(2): 181-197.

Litvak M (Ed.) (2009) Palestinian collective memory and national identity. London and New York: Palgrave Macmillan.

Meyers DG (2010) Social psychology. 10th Edition. New York: McGraw-Hill.

Nora P (1989) Between Memory and History: Les Lieux de Memoire. Representations: Special Issue 26: 7-24.

Pappe I (2006) The ethnic cleansing of Palestine. Oxford, England: Oneworld Publications.

Potter J, Edwards D (1990) Nigel Lawson's tent: discourse analysis, attribution theory and the social psychology of fact. European Journal of Social Psychology 20(5): 405-424. 
Potter J, Edwards D (1992) Discursive psychology. London: SAGE Publications.

Potter J, Wetherell M (1987) Discourse and social psychology: beyond attitude and behavior. London: SAGE Publications.

Shakespeare W (2009) Romeo and Juliet. Oxford: Oxford University Press.

Stokoe E, Edwards D (2006) Story formulations in talk-in-interaction. Narrative Inquiry 16(1): 56-65.

Weiner B (1986) An attributional theory of motivation and emotion. New York: SpringerVeralg.

Weiner B (1992) Human motivation: metaphors, theories, and research. SAGE Publications. 
